\title{
Evaluation and validation of flood hazard zoning using Analytical Hierarchy Process and GIS: A case study of Lam River basin (Vietnam)
}

Nguyen Ba Dung ${ }^{1}$, Nguyen Quynh Nga', Pham Thi Lan ${ }^{3}$, Le Thi Le ${ }^{4}$, Dang Tuyet Minh ${ }^{5}$

${ }^{1}$ Hanoi University of Natural Resources and Environment, 41A, Phu Dien Street, Phu Dien Ward, Bac Tu Liem District, Hanoi, Vietnam

${ }^{2}$ National Academy of Public Administration, 77, Nguyen Chi Thanh Street, Lang Thuong, Dong Da, Hanoi, Vietnam

${ }^{3}$ Hanoi University of Mining and Geology, 18, Vien Street, Duc Thang Ward, Bac Tu Liem District, Hanoi, Vietnam

${ }^{4}$ Thu Dau Mot University, 6, Tran Van On, Phu Hoa, Thu Dau Mot, Binh Duong, Vietnam

${ }^{5}$ Thuyloi University, 175, Tay Son, Trung Liet, Dong Da, Hanoi, Vietnam

For citation: Nguyen, Ba Dung, Nguyen, Quynh Nga, Pham, Thi Lan, Le, Thi Le, Dang, Tuyet Minh. (2021). Evaluation and validation of flood hazard zoning using Analytical Hierarchy Process and GIS: A case study of Lam River basin (Vietnam). Vestnik of Saint Petersburg University. Earth Sciences, 66 (4), 831-851. https://doi.org/10.21638/spbu07.2021.410

In recent years, the Lam river basin has suffered various forms of natural disasters such as floods, inundations, windstorms, tornadoes, etc. Among all these, the flood has proved to be the greatest threat to the people and the socioeconomic development in the basin. Moreover, it is very frequent as compared to other natural disasters. In view of the fact that such disastrous floods still occur in the basin, it becomes a necessity to determine the causes and analyze the components affecting flooding. This is important in order to develop an early flood warning system and thus minimize the negative impact of floods in the Lam river basin on the people and the facilities. In this paper, the analytical hierarchy process (AHP) analysis method integrated with GIS technology is used to map flood risk zones in the Lam river basin. The parameters used for the analysis are the main causes affecting the floods. In addition to the five most commonly used factors such as slope, rainfall, land cover, soil, and drainage density, this study also includes a new factor - relative slope length - to compute a more rigorous and reliable model. The results were compared with two more methods of flood hazard zoning in the same study area: the method of analyzing the main cause of the flood, and the method of inheriting, data analyzing, and processing. The results were also validated by the historical flood data of three years: 2010, 2013, and 2016.

Keywords: analytical hierarchy process (AHP), GIS, Lam river basin, flood hazard zone map, Vietnam.

\section{Introduction}

Vietnam is one of the ten countries most affected by global climate change (Kieu, 2015). Many extreme climatic phenomena have been affecting the livelihoods of the Viet-

(C) St. Petersburg State University, 2021 
namese people, in which floods are the most typical natural phenomenon and have been the major cause for great loss of wealth and life. Lam River, one of the largest river systems in North Central Vietnam, forms one of the basins in the country that is greatly affected by flooding. In the recent past, with growing industrialization, urbanization and global climate change, floods in the Lam river basin have become more frequent and even disastrous. According to the World Bank (2017), the total damage caused by floods and storms in 21 years from 1990 to 2010 was about 3300 billion VND. The flood in October 2016 caused nearly 1500 billion VND damage in Nghe An and Ha Tinh provinces (Hoa, 2016). In the historic flood of October 2017, Nghe An lost 10 lives, and material damage was 758 billion VND and Ha Tinh lost 375 billion VND (Binh, 2017).

In order to prevent and mitigate the damage caused by floods, it is essential to have an efficient early warning system. For this, firstly the flood hazard zones need to be mapped and assessed. In particular, for the Lam river basin, where the floods have high frequency and strength, it is necessary to systematize and zone the characteristics, properties, and patterns of flooding in the basin. This contributes to minimising the negative impacts of floods on the lives and livelihoods of residents in the basin.

In recent years, AHP has been used as an important tool in various research in Vietnam as well as other countries to evaluate and zone flood hazards (Tu et al., 2013). In Vietnam, Tu et al. (2013) conducted flood hazard zone mapping in the Vu Gia river basin using AHP and GIS; Phuong et al. (2015) applied the same strategy to construct a flood hazard zone map on the Huong river basin. Dung et al. (2020b) assessed the role of relative slope length in flood hazard mapping using AHP and GIS, and Dung et al. (2021c) evaluated the vulnerability of agricultural land in flood-prone areas based on the flood hazard zone map. The research used five parameters to compute the model, such as slope, soil, rainfall, landcover, and drainage density. AHP and GIS integration methodology is widely applied throughout the globe by various researchers (Fernández et al., 2010; Siddayao et al., 2014; Arianpour and Jamali, 2015; Kazakis et al., 2015; Rahmati et al., 2016) to map the flood hazard zones in their respective study areas. This method has also been used to establish flood risk maps by Gigović et al. (2017), Ghezelsofloo and Hajibigloo (2020) and to detect flood hazard areas by Lawal et al. (2012).

The input data of the published studies mainly comprise the hydrological and topographic datasets. The choice of data depends on the study area and type of the model or the used method. With the AHP method, the input data is relatively abundant. In this study, we used six flood risk impact factors belonging to the group of physical geographical factors to calculate the model. Unlike most of the previous studies that used slope, rainfall, drainage density, soil, and land cover, we have also considered relative slope length.

\section{The research area}

Being the largest river system in North Central Vietnam, the Lam river system is located within the geographic coordinates $103^{\circ} 14^{\prime} \mathrm{E}$ to $106^{\circ} 10^{\prime} \mathrm{E}$ longitude and $17^{\circ} 50^{\prime} \mathrm{N}$ to $20^{\circ} 50^{\prime} \mathrm{N}$ latitude. The river runs approximately a linear $350 \mathrm{~km}$ from northwest to southeast. The total basin area is $27200 \mathrm{~km}^{2}$, of which the territory of Vietnam in the basin has an area of $17730 \mathrm{~km}^{2}$ (Hung et al., 2014). This area covers a large part of Nghe An, Ha Tinh province, and a part of the Nhu Xuan district of Thanh Hoa province, as shown in Fig. 1. 


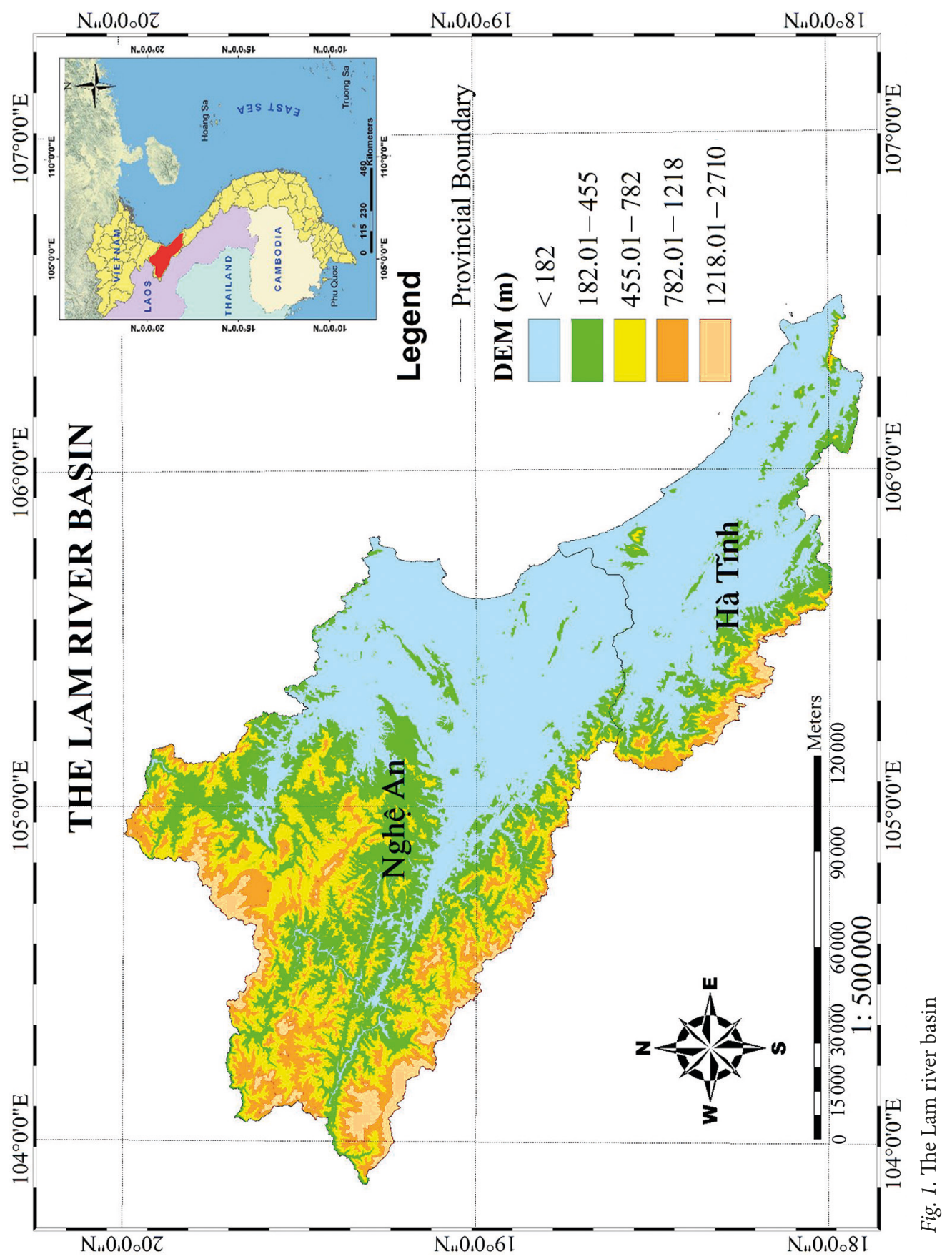


The Lam river basin has complex geography with three typical zones: the plains, midlands, and highlands. The topography generally slopes from the northwest to the southeast. In the south and southwest, the mountains have an average elevation of 1300 and $1800 \mathrm{~m}$, respectively. The Lam river system has two large tributaries, the Ca River and La River. The Ca River originates from Xieng Khouang Province (Laos) with an elevation of over $2000 \mathrm{~m}$, flows in the north-east-south direction with La River at Truong Xa and falls into the East Sea at Cua Hoi. From Truong Xa to the East Sea is called the Lam river. The main characteristics of rivers in the Lam river system originate from high mountains in the Truong Son range (Kieu and Thanh, 2011).

\section{The research methodology}

The study involved the use of various sources of data for the Lam river basin, which included topographic maps, land use maps, administrative boundary maps, morphological maps, maps of the locations of hydrological stations, and annual average rainfall data (from the period 1961-2017) at some locations in the basin. These data, obtained from concerned government agencies (Table 1), were used to build a map of factors affecting floods such as a slope map, land cover map, soil map, drainage density map, relative slope length map, and rainfall map. The index of flood risk was computed from the results of overlapping the above maps combined with the weight of factors affecting flooding. The weights were calculated by the AHP method.

The process of establishing a flood risk zone map is shown in Fig. 2, including the main steps: collecting and standardizing data, calculating the weight of each criterion, and constructing the map of the flood risk zone.

The weight of the criteria was assessed by the AHP method, which is one of the multi-criteria decision-making methods that was originally developed by Saaty (1987). It is a method to derive ratio scales from paired comparisons (Saaty, 1987). AHP is widely

Table 1. Data and its Sources

\begin{tabular}{|c|l|l|l|}
\hline Sr. No & \multicolumn{1}{|c|}{ Type of Data } & \multicolumn{1}{|c|}{ Sources } & \multicolumn{1}{|c|}{ Descriptions } \\
\hline 1 & Topographic map & Vietnam National Space Center & $\begin{array}{l}\text { Year 2015, } \\
\text { Scale 1:50000 }\end{array}$ \\
\hline 2 & Current land use map & $\begin{array}{l}\text { Department of Natural Resources and } \\
\text { Environment of Ha Tinh, Nghe An, and Thanh } \\
\text { Hoa provinces }\end{array}$ & $\begin{array}{l}\text { Year 2015, } \\
\text { Scale 1:50000 }\end{array}$ \\
\hline 3 & $\begin{array}{l}\text { Administrative } \\
\text { boundary map }\end{array}$ & $\begin{array}{l}\text { Department of Natural Resources and } \\
\text { Environment of Ha Tinh, Nghe An, and Thanh } \\
\text { Hoa provinces }\end{array}$ & $\begin{array}{l}\text { Year 2015, } \\
\text { Scale 1:50000 }\end{array}$ \\
\hline 4 & Morphological map & $\begin{array}{l}\text { Department of Natural Resources and } \\
\text { Environment of Ha Tinh, Nghe An, and Thanh } \\
\text { Hoa provinces }\end{array}$ & $\begin{array}{l}\text { Year 2015, } \\
\text { Scale 1:50000 }\end{array}$ \\
\hline 5 & $\begin{array}{l}\text { Location map of } \\
\text { hydrological stations }\end{array}$ & $\begin{array}{l}\text { Department of Natural Resources and } \\
\text { Environment of Ha Tinh, Nghe An, and Thanh } \\
\text { Hoa provinces }\end{array}$ & $\begin{array}{l}\text { Year 2015, } \\
\text { Scale 1:50000 }\end{array}$ \\
\hline 6 & $\begin{array}{l}\text { Annual average rainfall } \\
\text { data }\end{array}$ & $\begin{array}{l}\text { National Centre for Hydrometeorological } \\
\text { Forecasting }\end{array}$ & Period 1961-2017 \\
\hline
\end{tabular}




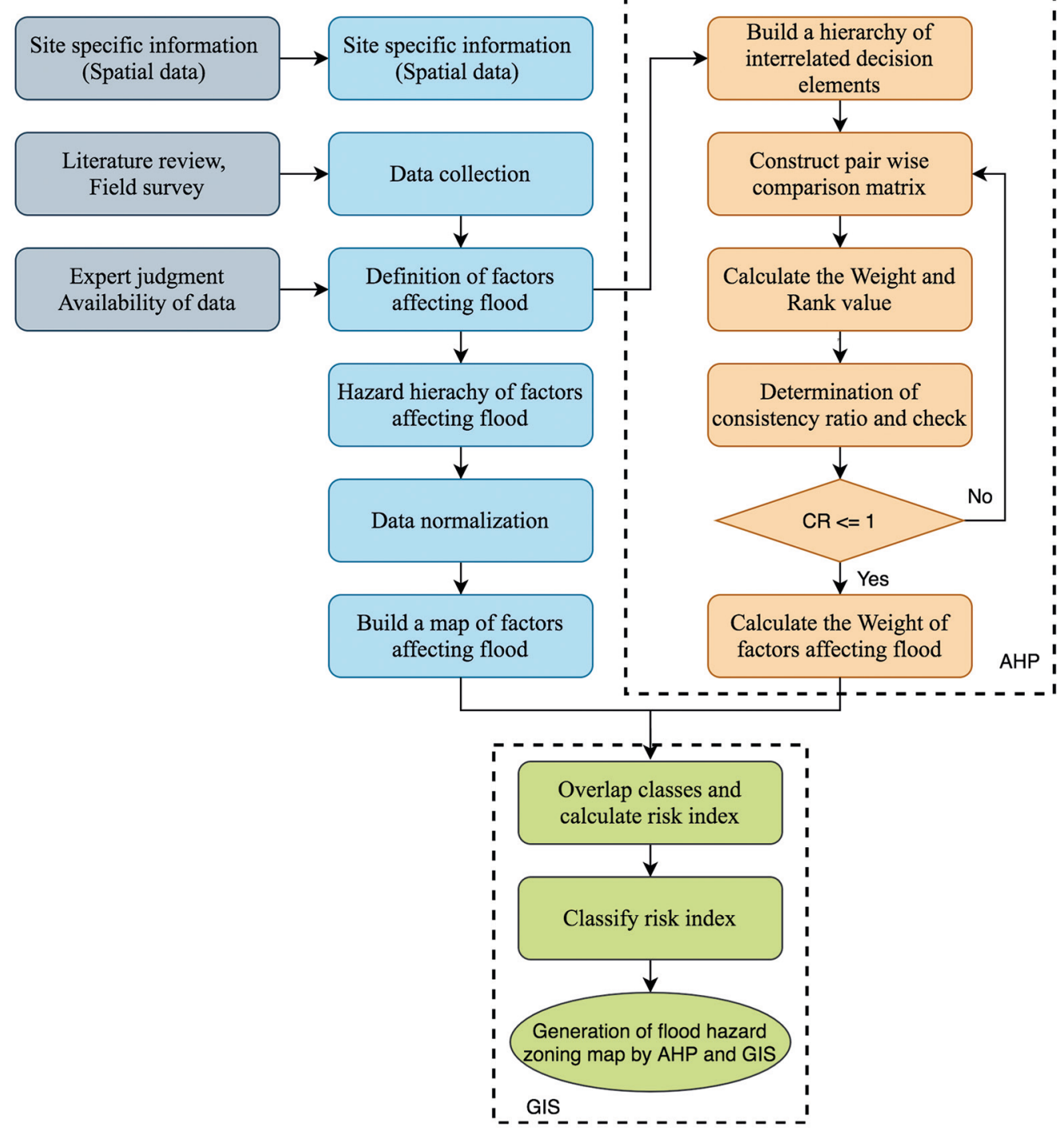

Fig. 2. Flowchart for the generation of flood hazard zoning maps

used in the evaluation of multiple criteria and goals in problems characterized by their complexity and subjectivity. This is entirely consistent with the objective of flood research, a natural phenomenon affected by many factors. According to Saaty (2008), the application of AHP comprises the following stages: the structuring of criteria and alternatives; collecting judgments; calculating priorities; checking the consistency of judgments; and lastly, calculating the overall priorities of the alternatives.

In order to zone flood hazard using AHP, firstly it is necessary to define the main elements affecting flooding, based on causes, characteristics, formation mechanisms, physical geographical conditions, socioeconomic conditions, etc. The next step is to model the problem into a hierarchical structure with the relationship between goal, objectives, 
and alternatives. However, according to Miller (1956), we must use a maximum of $7 \pm 2$ elements in each level to achieve higher accuracy in the comparisons. If there are $\mathrm{n}$ factors then the number of comparisons will be $n(n-1) / 2$. Also, according to Saaty (1987), the factors are compared from a square matrix, whose order is equal to the number of elements subordinate to the next higher node. Subordinate elements are arranged in the same order, forming the rows and columns of the matrix.

When zoning flood hazards, the factors affecting flooding have different roles and importance. Hence, assessors must consider the most important element based on the focus criterion and the intensity of this element. For the assessment, each factor in the row is compared with each column criterion, and the score of the judgment is then registered in the matrix corresponding to the compared elements. In this study, the coefficient of the matrix is calculated from the score of pairwise comparison of these criteria through expert judgment on areas such as the environment, water resources, sociology, geodesy, hydrology, soil, meteorology, etc. The relative importance between two criteria is measured according to a numerical scale from 1 to 9 , as shown in Table 2. Pairwise judgments are made based on the best information available and the decision maker's knowledge and experience, consultation, and subjectiveness.

Table 2. Saaty's scale for weight assignment (Saaty, 1987)

\begin{tabular}{|c|l|l|}
\hline $\begin{array}{c}\text { Numerical } \\
\text { rating }\end{array}$ & \multicolumn{1}{|c|}{ Definition } & \multicolumn{1}{c|}{ Description } \\
\hline 1 & Equally preferred & Two factors contribute equally to the objective \\
\hline 3 & Moderately preferred & Experience and judgment slightly favor one over the other \\
\hline 5 & Strongly preferred & Experience and judgment strongly favor one over the other \\
\hline 7 & Very strongly preferred & $\begin{array}{l}\text { Experience and judgment very strongly favor one over the } \\
\text { other. Its importance is demonstrated in practice }\end{array}$ \\
\hline 9 & Extremely preferred & $\begin{array}{l}\text { The evidence favoring one over the other is of the highest } \\
\text { possible validity }\end{array}$ \\
\hline $2,4,6,8$ & Intermediate values & When compromise is needed \\
\hline
\end{tabular}

The weight of the criteria can be calculated using two methods: the eigenvector method and the normalization matrix method. The priority vector shows relative weights among the things that we compare. In this study, the latter method was used to get the weight of the factors. The larger the weight of a criterion becomes, the more that criterion affects the risk of flood. Once a pairwise comparison matrix is built, a normalized pairwise comparison matrix $A_{\text {norm }}$ is constructed. Each entry $w_{\mathrm{ij}}$ of the matrix $\mathrm{A}_{\text {norm }}$ is computed as

$$
w_{i j}=\frac{a_{i j}}{\sum_{i=1}^{n} a_{i j}},
$$

$a_{\mathrm{ij}}$ are the entries of a pairwise comparison matrix A.

The criteria weight vector $\mathrm{W}$ ( $n$ - dimensional column vector) is built by averaging the entries on each row of $A_{\text {norm }}$, i. e. 


$$
\mathrm{W}_{i}=\frac{\sum_{j=1}^{n} w_{i j}}{n} .
$$

The consistency of the created eigenvector matrix for AHP needs to be evaluated. The required level of consistency is evaluated using the following index (Drobne and Lisec, 2009):

$$
\mathrm{CR}=\frac{\mathrm{CI}}{\mathrm{RI}},
$$

$\mathrm{RI}$ is the random index, represents an average number that is selected according to a particular number of matrix rows or the number of criteria being compared, $\mathrm{CI}$ is the consistency index which is given as

$$
\mathrm{CI}=\frac{\lambda_{\max }-n}{n-1},
$$

$n$ is the number of criteria, represents the number of independent rows of the matrix, $\lambda_{\max }$ is the biggest eigenvalue (maximum value of matrix).

If the value of the consistency ratio CR is smaller or equal to $10 \%$, the inconsistency is acceptable. If the consistency ratio CR is greater than $10 \%$, it is necessary to consider revising the subjective judgments.

The basis of flood risk zoning is generalized into the equation for calculating the risk score according to the hierarchy score of factors; these criteria are selected in a group of topographic, socioeconomic, or infrastructure criteria:

$$
Y=w_{1} X_{1}+w_{2} X_{2}+\ldots+w_{n} X_{n}
$$

in which $Y$ is risk score, $X_{i}$ is hierarchy score of factor $i(I=1-n), w_{i}$ is the weight of factor $i$.

For each component element, it is necessary to establish hierarchical maps and assess them at each level according to Saaty's scale ranges (Saaty's, 1987). These computed datasets are then further used to determine the grades of the flood hazard areas.

\section{Results and discussion}

\subsection{Determining the weight of the criteria affecting flooding}

The coefficients of the pairwise comparison matrix were calculated from the results of the comparison of the influential criteria through the survey questionnaire from experts and scientists representing fields such as environment, water resources, geodesy, soil, hydrology, hydraulics, sociology, and meteorology. The comparison results are shown in Table 3 (Dung et al., 2020a).

The normalized matrix method was applied to calculate the weight of the factors affecting the flood. The importance of each criterion can be determined through the weights shown in Table 4 . The computation shows that rainfall is the most dominant factor $(45 \%)$ for floods while the soil is the least affecting factor $(6.8 \%)$ among all the six chosen factors.

After determining the weight of the influencing factors, it is necessary to calculate the parameters of the comparison matrix (Table 5). From the consistency ratio CR, it is possible to measure the degree to which judgments are not coherent. In this study, CR was 
Table 3. Pairwise comparison matrix for six factors influencing flood risk

\begin{tabular}{|l|c|c|c|c|c|c|}
\hline \multicolumn{1}{|c|}{ Criteria } & Rainfall & Soil & Slope & $\begin{array}{c}\text { Land } \\
\text { cover }\end{array}$ & $\begin{array}{c}\text { Drainage } \\
\text { density }\end{array}$ & $\begin{array}{c}\text { Relative slope } \\
\text { length }\end{array}$ \\
\hline Rainfall & 1 & 7 & 3 & 5 & 5 & 5 \\
\hline Soil & $1 / 7$ & 1 & $1 / 5$ & 1 & 1 & 1 \\
\hline Slope & $1 / 3$ & 5 & 1 & 5 & 3 & 3 \\
\hline Land cover & $1 / 5$ & 1 & $1 / 5$ & 1 & 1 & 1 \\
\hline Drainage density & $1 / 5$ & 1 & $1 / 3$ & 1 & 1 & 1 \\
\hline Relative slope length & $1 / 5$ & 1 & $1 / 3$ & 1 & 1 & 1 \\
\hline
\end{tabular}

Table 4. The weight of influential criteria

\begin{tabular}{|l|c|}
\hline \multicolumn{1}{|c|}{ Criteria } & Weight \\
\hline Rainfall & 0.450 \\
\hline Slope & 0.255 \\
\hline Relative slope length & 0.077 \\
\hline Drainage density & 0.077 \\
\hline Land cover & 0.073 \\
\hline Soil & 0.068 \\
\hline
\end{tabular}

Table 5. Parameters of AHP

\begin{tabular}{|l|c|}
\hline \multicolumn{1}{|c|}{ Parameters } & Value \\
\hline Eigen value of a matrix $\left(\lambda_{\max }\right)$ & 6.18 \\
\hline The number of criterion $(n)$ & 6 \\
\hline Consistency index $(\mathrm{CI})$ & 0 \\
\hline Random index (RI) & 1.24 \\
\hline Consistency ratio (CR) & 0.03 \\
\hline
\end{tabular}

equal to 0.03 (less than 0.1 ), so these weights are acceptable because the evaluation of the experts is relatively consistent. Therefore, it is possible to build a flood risk zone map for the study area.

\subsection{Establishing the hierarchy table and the hierarchy map of factors affecting flooding in the Lam river basin}

The hierarchy table was established based on the relationship between flood level and characteristics of influence factors to assess each criterion affecting flooding according to five levels: very low, low, medium, high, and very high (corresponding to scores from 1 to 9).

\subsubsection{Rainfall}

The average annual precipitation in the Lam river basin fluctuates from 1000 to $2900 \mathrm{~mm}$. The intensity of the rainfall is directly proportional to the flood risk. The effect of rainfall on flood hazard will be hierarchical gradually from a very low level to a very high level, corresponding to rainfall from less than $1200 \mathrm{~mm}$ to greater than $2400 \mathrm{~mm}$, as shown in Table 6.

Average rainfall in the period from 1961 to 2017 was used to establish a rainfall distribution map of the Lam river basin. From the precipitation map, the rainfall hierarchy 
Table 6. Rainfall Hierachy

\begin{tabular}{|c|c|c|c|}
\hline No. & Rainfall, $\mathbf{m m}$ & Mark & Level of flood risk \\
\hline 1 & $<1200$ & 1 & Very Low Hazard \\
\hline 2 & $1200-1600$ & 3 & Low Hazard \\
\hline 3 & $1600-2000$ & 5 & Moderate Hazard \\
\hline 4 & $2000-2400$ & 7 & High Hazard \\
\hline 5 & $>2400$ & 9 & Very High Hazard \\
\hline
\end{tabular}

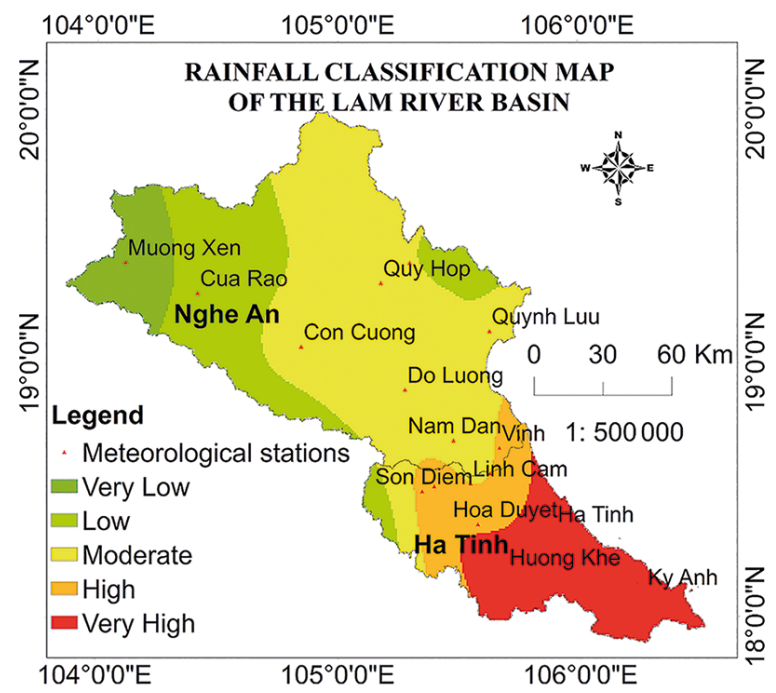

Fig. 3. Rainfall hierarchy map of the Lam River Basin

map (Fig. 3) with five levels influencing flood hazard was built by combining areas with the same level of risk as Table 6 .

\subsubsection{Slope}

In the Lam river basin, the average slope of the sub-basins is $18.3 \%$. The flood flow increases or decreases as the slope changes, so the level of impact on flood risk varies. The lower the slope, the higher the flood hazard (Gigović et al., 2017; Kazakis et al., 2015; Sohl and Benjamin, 2012). With the slope hierarchy, made up of five levels corresponding to five types of terrain, as shown in Table 7, the lowest slope area is considered the highest flood risk and vice versa - the highest slope region will have the lowest flood risk. Therefore, the risk level increases from very low for the largest slope regions to very high for the smallest slope areas. Based on the digital elevation model (DEM), we used a raster spatial analysis problem to interpolate a slope map. The slope map of the Lam river basin shows five slope values, as shown in Table 7. Since then, the slope hierarchy map was made, with five levels affecting flood hazard, shown in Fig. 4. 
Table 7. Slope Hierarchy

\begin{tabular}{|c|c|c|c|}
\hline No. & Slope & Mark & Level of flood risk \\
\hline 1 & $<25^{\circ}$ & 1 & Very Low Hazard \\
\hline 2 & $15-25^{\circ}$ & 3 & Low Hazard \\
\hline 3 & $8-15^{\circ}$ & 5 & Moderate Hazard \\
\hline 4 & $3-8^{\circ}$ & 7 & High Hazard \\
\hline 5 & $<3^{\circ}$ & 9 & Very High Hazard \\
\hline
\end{tabular}

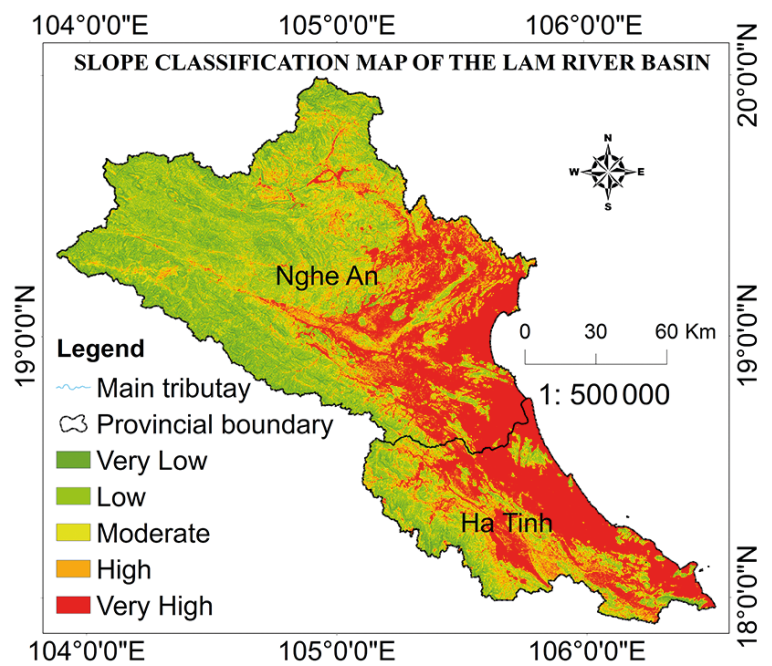

Fig. 4. Slope hierarchy map of the Lam River Basin

\subsubsection{Soil}

The Lam river basin has a diverse and complex geological structure, with a diversity of original rock compositions leading to an abundance of terrain types and creating distinct soil characteristics. High permeability soils reduce surface flow, which means that the flood risk decreases, and vice versa. Based on the permeability of different soil types in the study area, the soil factor was hierarchized according to the extent of its impact on the flood risk, as shown in Table 8.

Table 8. Soil Hierachy

\begin{tabular}{|c|l|c|c|}
\hline No. & \multicolumn{1}{|c|}{ Soil type } & Mark & Level of flood risk \\
\hline 1 & C, $\mathrm{Cc}$ & 1 & Very Low Hazard \\
\hline 2 & A, $\mathrm{Ha}, \mathrm{Hq}, \mathrm{Hs}$ & 3 & Low Hazard \\
\hline 3 & Fk, Fp, Fv, Nt, B, Ba, Bq, Fa, Fj, Fq, P, Pb, Pf, Py, R, Rdv, Rk & 5 & Moderate Hazard \\
\hline 4 & D, Fl, Fs, SM, Sj1Mi, Sj2Mi, M, Mi, Mm, Mn, Pg, Pj & 7 & High Hazard \\
\hline 5 & E, Nu & 9 & Very High Hazard \\
\hline
\end{tabular}




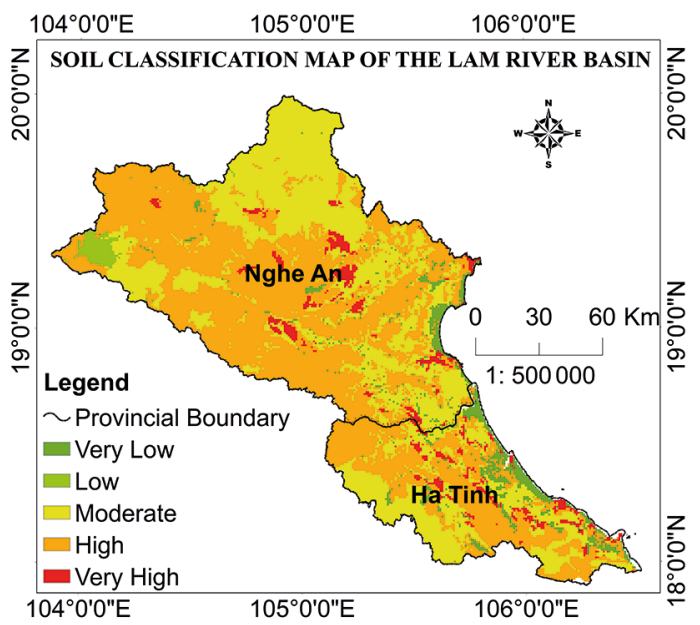

Fig. 5. Soil hierarchy map of Lam River Basin

The soil hierarchy map (Fig. 5), with five levels affecting the risk of flood, was built by combining soil types with the same level of impact on flood risk and score, classified in Table 8.

\subsubsection{Landcover}

The lower the water retention and soil protection, the higher the probability of flood hazard. Based on the features of covers, forest, water retention, and soil protection capacity, land cover in the Lam river basin was hierarchized according to its impacts on flood hazard from very low to very high, with scores from 1 to 9 , as shown in Table 9.

Table 9. Land Cover Hierachy

\begin{tabular}{|c|l|c|c|}
\hline No. & \multicolumn{1}{|c|}{ Land cover } & Mark & Level of flood risk \\
\hline 1 & Broadleaf evergreen forest (high, medium, low reserve) & 1 & Very Low Hazard \\
\hline 2 & Renew forest, mixed bamboo forest & 3 & Low Hazard \\
\hline 3 & Residential land, other land & 5 & Moderate Hazard \\
\hline 4 & Shrubs, agricultural land, bare lands & 7 & High Hazard \\
\hline 5 & Cultivated aquatic land & 9 & Very High Hazard \\
\hline
\end{tabular}

The main data source used to compile this map was the current land use map of the Lam river basin and the land cover data collected in the study area. The land cover hierarchy map (Fig. 6), with five levels affecting flood risk, was made by pooling the types of soils that have the same level of impact on flood risk in Table 9.

\subsubsection{Drainage density}

Drainage density is a classical descriptor of catchment morphology which is known to control the formation of river flows. As such, it may significantly influence the 


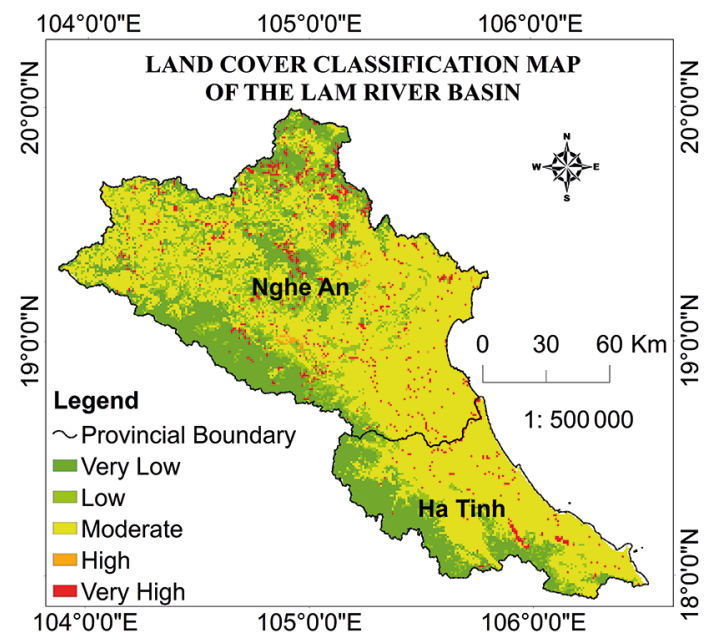

Fig. 6. Land cover hierarchy map of Lam River Basin

frequency regime of flood flows (Pallard et al., 2009). Drainage density in the Lam river basin is quite complicated because of its complex terrain and high slope. The average density is about $0.60 \mathrm{~km} / \mathrm{km}^{2}$ and develops unevenly. The drainage density hierarchy in Table 10 was defined based on the fact of direct proportionality among the drainage density and the level of flood risk.

Table 10. Drainage density Hierarchy

\begin{tabular}{|c|c|c|c|}
\hline No. & $\begin{array}{c}\text { Drainage density, } \\
\mathbf{k m} / \mathbf{k m}^{2}\end{array}$ & Mark & Level of flood risk \\
\hline 1 & $\mathrm{D}<0.5$ & 1 & Very Low Hazard \\
\hline 2 & $\mathrm{D}=0.5-1.0$ & 3 & Low Hazard \\
\hline 3 & $\mathrm{D}=1.0-1.5$ & 5 & Moderate Hazard \\
\hline 4 & $\mathrm{D}=1.5-2.0$ & 7 & High Hazard \\
\hline 5 & $\mathrm{D}>2.0$ & 9 & Very High Hazard \\
\hline
\end{tabular}

The DEM data and river system map of the Lam river basin was used in combination with the Spatial Analysis Tools in ArcGIS 10.2 software to determine the area of sub-basins, the length of the river, and the stream systems. These results were used to determine the drainage density index (Minh and Dung, 2018). The corresponding drainage density hierarchy map is shown in Fig. 7.

\subsubsection{Relative slope length}

Slope length is an effective factor in relation to runoff volume. This factor has been defined as the distance from the point of origin of overland flow to either of the following, whichever is limiting for the major part of the area under consideration: (a) the point 


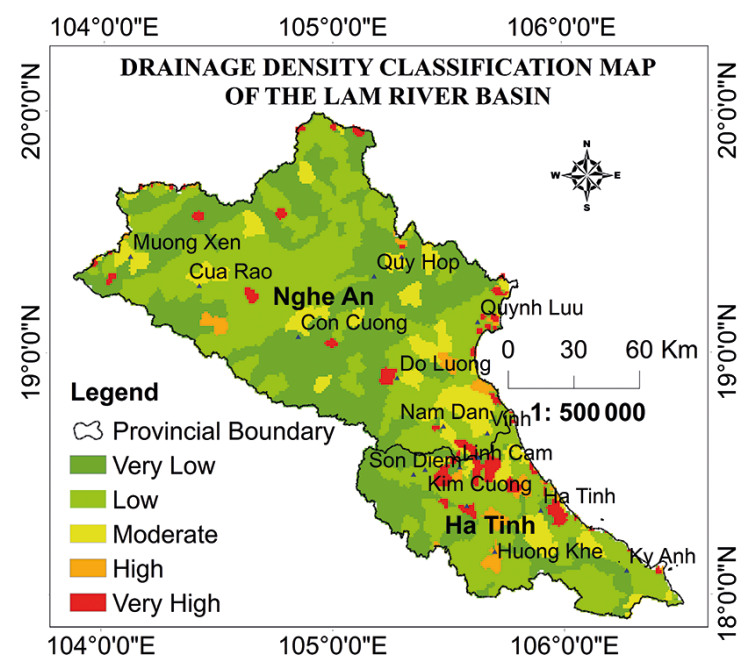
Basin

Fig. 7. Drainage density hierarchy map of Lam River

Table 11. Relative slope length Hierarchy

\begin{tabular}{|c|c|c|c|}
\hline No. & Relative slope length & Mark & Level of flood risk \\
\hline 1 & $<20 \%$ & 1 & Very Low Hazard \\
\hline 2 & $20-40 \%$ & 3 & Low Hazard \\
\hline 3 & $40-60 \%$ & 5 & Moderate Hazard \\
\hline 4 & $60-80 \%$ & 7 & High Hazard \\
\hline 5 & $80-100 \%$ & 9 & Very High Hazard \\
\hline
\end{tabular}

where the slope decreases to the extent that deposition begins, or (b) the point where runoff enters a well-defined channel that may be part of a drainage network or a constructed channel such as a terrace or diversion (Wischmeier and Smith, 1978). The slope length is more meaningful in the calculation of hydrological and hydraulic models, but it is difficult in the hierarchy to determine the weight for the AHP method. Thus, the author suggested using the relative slope length in his research. The relative slope length is the length of a segment relative to the length of the whole slope (Dung et al., 2020b).

In reality, water accumulates gradually in the moving process along the flank from high to low. Flooding often occurs in the lower flank, so slope length is a factor that affects floods and flood formation. However, the length from the watershed line to the valley line is different for each slope. Therefore, the slope length hierarchy according to the flood hazard level is not categorized by the specific length of each slope but by the percentage. If the length of a slope is considered to be $100 \%$, the level of risk at one location will be equivalent to the distance from the watershed line to that location and hierarchized as in Table 11. Accordingly, the area with the closest distance to the watershed line will be assigned the lowest risk level corresponding to the lowest point, and the level of risk increases when the distance increases. 


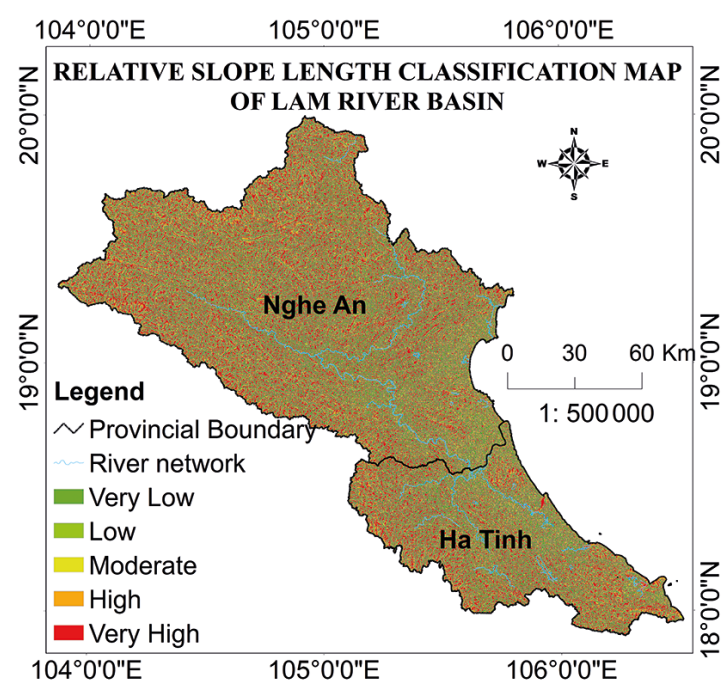

Fig. 8. Relative slope length hierarchy map of Lam River Basin

From the DEM of the study area, it was possible to identify the watershed line, the valley line, and the slope length. A relative slope length map was established, from which the relative slope length hierarchical map was constructed (Fig. 8).

\subsection{Establish flood hazard zoning map of Lam river basin}

After the successful compilation of the impact criteria maps and weight determination for the factors affecting the flood, a flood risk zone map was generated using the spatial analysis method in the GIS environment (Fig. 9). It is the integration of component maps; each pixel of the output hazard map was calculated using the following equation:

$$
\begin{aligned}
& Y=0.45 \mathrm{Map}_{\text {Rainfall }}+0.255 \mathrm{Map}_{\text {Slope }}+0.077 \mathrm{Map}_{\text {Relative slopelength }}+ \\
& +0.077 \text { Map } p_{\text {Drainage density }}+0.068 \mathrm{Map}_{\text {Soil }}+0.073 \mathrm{Map} \mathrm{p}_{\text {Landcover }} \text {, }
\end{aligned}
$$

Map Rainfall is the value of the position on the rainfall map, Map slope is the value of the position on the slope map, Map Relativeslopelength is the value of the position on the relative slope length map, Map Drainage density is the value of the position on the drainage density map, Map $p_{\text {Soil }}$ is the value of the position on the soil map, Map $p_{\text {Landcover }}$ is the value of the position on the land cover map.

The integrated processing result is a map with each pixel having a corresponding $\mathrm{Y}$ value score. To build a flood hazard zone map, the $\mathrm{Y}$ values on the numerical value map should be divided into appropriate risk levels. Calculated results show that the risk score is between 1.30 and 8.40 , so it is possible to divide into four risk levels. Table 12 shows the categorization of the flood risk index and corresponding risk areas in the Lam river basin. Figure 10 shows the area ratio of a flood risk area for the study area. 


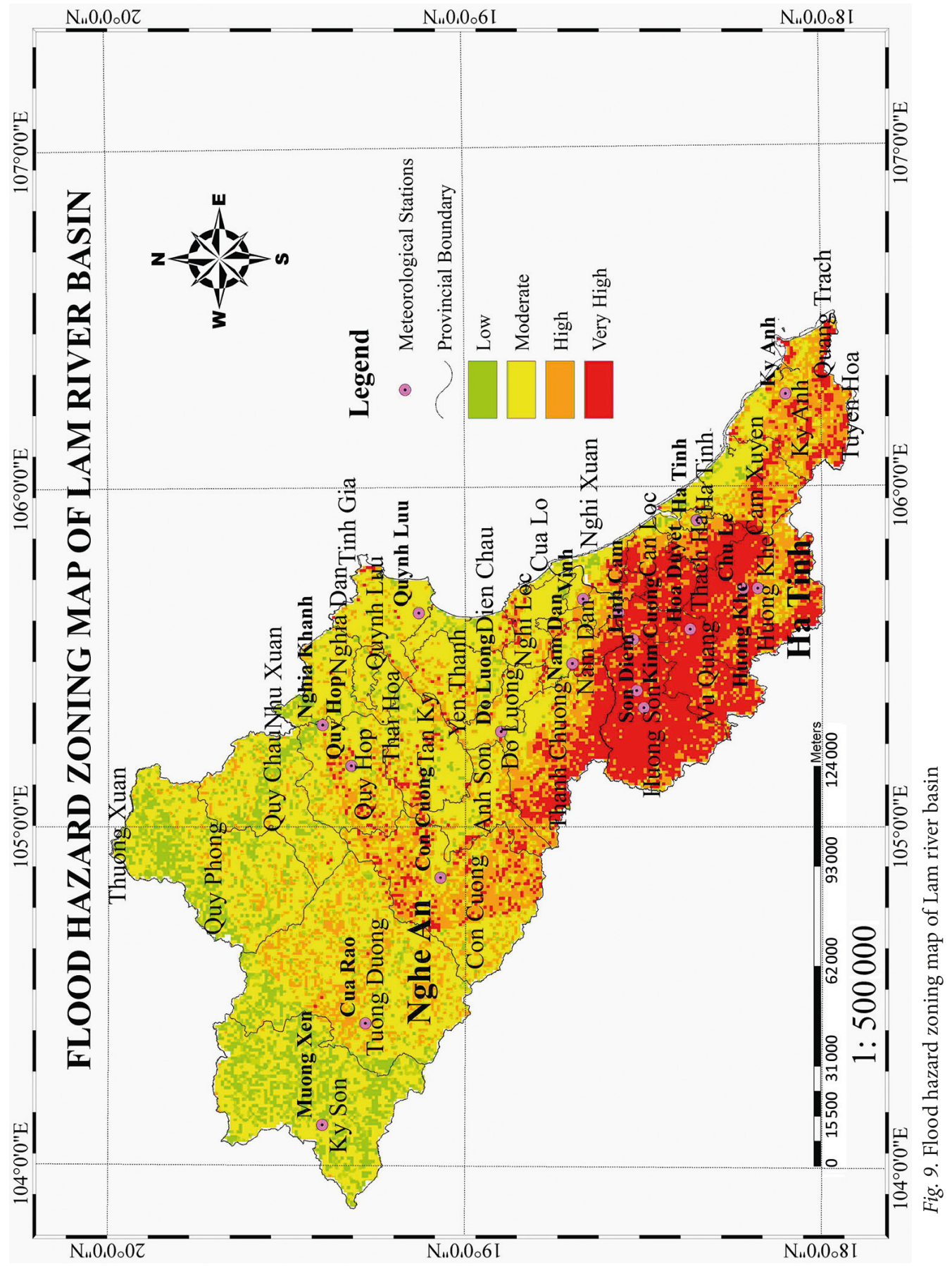




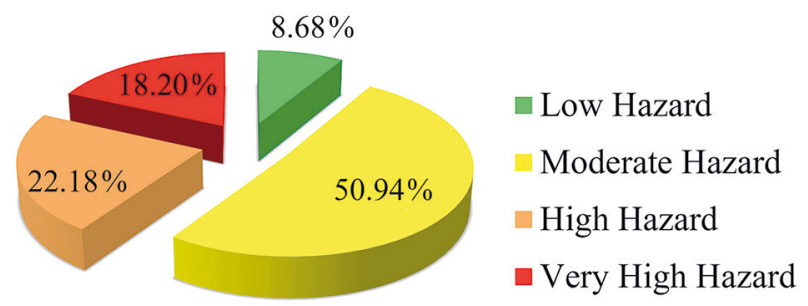

Fig. 10. Percentage of flood risk classes in the study areas

Table 12. Categorization of the flood risk index in Lam river basin

\begin{tabular}{|c|c|c|c|c|l|}
\hline $\begin{array}{c}\text { Hazard } \\
\text { level }\end{array}$ & $\begin{array}{c}\text { Range } \\
\text { of the Flood } \\
\text { Risk Index }\end{array}$ & $\begin{array}{c}\text { Risk } \\
\text { Level }\end{array}$ & $\begin{array}{c}\text { Area, } \\
\mathbf{k m}^{2}\end{array}$ & $\%$ & \multicolumn{1}{|c|}{ Hazard area } \\
\hline 1 & $1.3-3$ & Low & 1911.21 & 8.68 & $\begin{array}{l}\text { Ky Son, Thuong Xuan, Quy Phong, Quy Chau, } \\
\text { Nhu Xuan districts }\end{array}$ \\
\hline 2 & $3-5$ & Moderate & 11213.90 & 50.94 & Scattered accross the basin \\
\hline 3 & $5-7$ & High & 4883.97 & 22.18 & $\begin{array}{l}\text { District of Tuong Duong, Quy Hop, Con Cuong, } \\
\text { a part of Thanh Chuong, Nam Dan, Hong Linh } \\
\text { districts, some of the eastern districts of Ha } \\
\text { Tinh: Cam Xuyen, and Ky Anh }\end{array}$ \\
\hline 4 & $>7$ & Very High & 4005.95 & 18.20 & $\begin{array}{l}\text { Huong Son, Vu Quang, Huong Khe districts and } \\
\text { a part of districts: Thanh Chuong, Duc Tho, Can } \\
\text { Loc, Thach Ha, and Cam Xuyen }\end{array}$ \\
\hline
\end{tabular}

\subsection{Assessing the reliability of the results of flood hazard zoning in the Lam river basin}

The results of the study using the method of flood risk zoning by AHP (method 1) were compared with the results of flood hazard zoning conducted by Kieu (2011) using analysis of the main cause of flooding (method 2). It was also compred with the results of flood hazard zoning by Kieu (2015) using the method of inheriting, data analyzing and processing (method 3). All three methods produced the following results: (a) in the Lam river basin, the area upstream of the Ca River, and the Hieu River have the lowest level of flood risk, (b) the biggest risk is upstream of the Ngan Pho River and the junction of the La River with the Ca River, limited by the Nam Dan hydrological station of the Ca river branch, Son Diem hydrological station of the Ngan Pho river branch, and Hoa Duyet hydrological station of the Ngan Sau river branch. However, with the AHP method, it was observed that high flood risk can also occur in the area upstream of the Ngan Sau river extending to Chu Le, Huong Khe, and Ha Tinh hydrological stations.

In addition, the study results can be verified based on flood alarm level at the hydrological stations (Do Luong, Son Diem, Hoa Duyet, Linh Cam, and Nam Dan) in the study area with three flood events: October 16-18, 2010; October 15-16, 2013; October 15-16, 2016. 
Three levels of flood alarms correspond to the level of hazard in the study as follows:

- above alarm 3: very high flood risk;

- above alarm 2: high flood risk;

- above alarm 1: medium flood risk;

- under alarm 1: low flood risk.

Comparison of the alarm level at some hydrological stations with the results of flood risk zoning of this study shows that:

- for the flood on October 16-18, 2010, the results at 5 hydrological stations are realistic;

- for the flood on October 15-16, 2013, the result at Linh Cam hydrological station has a small difference. Actually, the alarm at this station was only below alarm level 3 (equivalent to a high level risk) but the risk level was deemed very high in this study;

- for the flood on October 15-16, 2016, there is also a small difference at Linh Cam and Son Diem hydrological stations. Actually, the alarm at these stations was only below alarm 3 (equivalent to a high level of risk) but the hazard level was deemed very high in this study.

Thus, there is a small difference between the flood hazard zone map using the AHP method and actual results. This difference is due to the zone mapping of the study area using data on soil, land cover, relative slope length, and drainage density in 2015 and average rainfall data from 1961 to 2017 . However, the study also shows that most areas with very high flood risks are relatively similar to real occurrences and two other assessment methods (Kieu, 2011; 2015) as well. In particular, with the AHP method, the Chu Le area is always at high flood risk and consistent with the alarm level 3 of many floods.

The obtained results revealed that AHP provides a flexible, simple, step-by-step, and transparent approach to analyze complex problems in a multi-criteria decision analysis environment based on experts' knowledge, experience, and judgments. Furthermore, integration of GIS technology and the analytic hierarchy process to assess flood hazard is considered relatively inexpensive, easy to use, and more importantly, permits interactive implementation by flood managers for continuing improvement (Dung et al., 2021b). The method and affected factors in the present research can be applied to other sites with similar characteristics. This method can be applied anywhere in the world, but the selection of influence criteria will not be the same for different regions. According to Dung et al. (2021a), choosing the appropriate factors to delineate the flood-prone areas by the AHP method is dependent on the physical geographic conditions of the research area as well as the available data. Therefore, careful consideration is needed to decide which factors can be chosen, determine the matching capacity of these elements on the hierarchy, and use the AHP algorithm for computation. In addition, it is not recommended to use too many criteria; a maximum of nine criteria is sufficient because psychologists conclude that nine objects are the most that an individual can simultaneously compare and consistently rank (Paweł, 2010). 


\section{Conclusions}

In this study, a flood hazard zone map was produced using the AHP method and GIS. This is one of the useful methods for forecasting, preventing and mitigating damages caused by floods as well as limiting ecological damage in the future. This study is consistent with the results of previous research as well as flood alarm levels at the hydrological stations in the study area with three flood events. The relative importance of each parameter is calculated by the AHP method. Six parameters, including rainfall, slope, land use, drainage density, relative slope length, and soil were presented to the experts for paired comparison and assigning of weight as the main criteria for flood hazard mapping in the framework of GIS. The highest weight was assigned to rainfall and the lowest to the soil. This calculation resulted in a $0.03 \%$ consistency ratio. Following that, the effect of each factor was combined together and their numerical superimposition resulted in mapping flood-prone areas. The flood hazard areas of the Lam river basin were classified into four categories: low, medium, high, and very high. From the flood hazard zone map, the risk areas at different levels can be determined. The proposed methodology also showed that 22.18 and $18.2 \%$ of the study area belong to high and very high hazard classes, respectively. The southwestern and southern part of Ha Tinh province - Huong Son, Vu Quang, Huong Khe districts and a part of Thanh Chuong, Duc Tho, Can Loc, Thach Ha, and Cam Xuyen districts - presents the highest flood hazard. This area is characterized by intense rainfall and high slope.

This study shows evidence of the importance and reliability of the application of a mixed GIS and AHP approach in the assessment of phenomena that require expert opinions and manipulate a large number of data from different sources. In particular, using the GIS-based AHP method in flood hazard studies is of great importance in the case of multiple criteria and conflicting objectives. The results of this study provide a good basis for developing a system of flood hazard management in river basin areas and can be successfully used for spatial development strategies.

Research results also show that the flood hazard in the basin is quite serious. It is therefore necessary to build an information system to regularly update the natural conditions and the socio-economic development in river basins in Vietnam to augment the accuracy and reliability of the flood hazard zoning results and the forecast of flooding on river basins. With this study, there are timely and app ropriate coping options to minimize damage.

\section{References}

Arianpour, M. and Jamali, A. (2015). Flood Hazard Zonation using Spatial Multi Criteria Evaluation (SMCE) in GIS (Case Study: Omidieh-Khuzestan). European Online Journal of Natural and Social Sciences, [online] 4 (1), 39-49. Available at: https://www.researchgate.net/publication/274780949_Flood_hazard_zonation_using_spatial_multi-criteria_evaluation_SMCE_in_GIS_Case_study_Omidieh-Khuzestan [Accessed 20 Dec. 2021].

Binh, H. (2017). 10 people died in Nghe An, more than 700 billion VND in damage due to floods. [online] Available at: VNExpress. https://vnexpress.net/nghe-an-10-nguoi-chet-thiet-hai-hon-700-ty-dongdo-mua-lu-3658992.html [Accessed 20 Dec. 2021]. (In Vietnamese)

Dung, N. B., Minh, D. T., Long, N. Q. and Ha, L. T. T. (2020a). Weight of factors contributing to flood formation in the Lam river basin, Vietnam. SW Jiaotong Univ., 55 (2). https://doi.org/10.35741/issn.02582724.55.2.50 
Dung, N. B., Minh, D. T., Ahmad, A. and Long, N. Q. (2020b). The role of relative slope length in flood hazard mapping using AHP and GIS (case study: Lam River Basin, Vietnam). Geogr. Environ. Sustain., [online] 13 (2), 115-123. Available at: https://ges.rgo.ru/jour/article/view/1164 [Accessed 20 Dec. 2021].

Dung, N. B., Long, N. Q., An, D. T. and Minh, D. T. (2021a). Multi-geospatial flood hazard modelling for a large and complex river basin with data sparsity: a case study of the Lam River Basin, Vietnam. Earth Systems and Environment. https://doi.org/10.1007/s41748-021-00215-8

Dung, N. B., Long, N. Q., Ropesh, G., An, D. T. and Minh, D. T. (2021b). The Role of Factors Affecting Flood Hazard Zoning Using Analytical Hierarchy Process: A Review. Earth Systems and Environment. https://doi.org/10.1007/s41748-021-00235-4

Dung, N. B., Minh, D. T., An, B. N. and Nga, N. Q. (2021c). Assessment of vulnerability In agricultural land in flood prone Areas and application of mobile smart Phone in providing flood hazard Information in lam river Basin (Vietnam). Sustainable development of mountain territories, 2 (48), 254-265. https:// doi.org/10.21177/1998-4502-2021-13-2-254-264

Drobne, S. and Lisec, A. (2009). Multi-attribute Decision Analysis in GIS: Weighted Linear Combination and Ordered Weighted Averaging. Informatica, [online] 33 (4), 459-474. Available at: https://www. researchgate.net/publication/220166125_Multi-attribute_Decision_Analysis_in_GIS_Weighted_Linear_Combination_and_Ordered_Weighted_Averaging [Accessed 20 Dec. 2021].

Fernández, D. S. and Lutz, M. A. (2010). Urban flood hazard zoning in Tucumán Province, Argentina, using GIS and multicriteria decision analysis. Engineering Geology, 111, 90-98. https://doi.org/10.1016/j. enggeo.2009.12.006

Gigović, L., Pamučar, D., Bajić, Z. and Drobnjak, S. (2017). Application of GIS-Interval Rough AHP Methodology for Flood Hazard Mapping in Urban Areas. Water, 9 (6), 360, https://doi.org/10.3390/w9060360

Ghezelsofloo, A. A. and Hajibigloo, M. (2020). Application of Flood Hazard Potential Zoning by using AHP Algorithm. Civil Engineering Research Journal, 9 (5), 150-159.

Hoa, D. (2016). Floods cause damage to Ha Tinh and Nghe An nearly 1,500 billion VND. [online] Tuoitre online. Available at: https://tuoitre.vn/mua-lu-lam-ha-tinh-nghe-an-thiet-hai-gan-1500-tidong-1191136.htm [Accessed 20 Dec. 2021].

Hung, N. Q., Son, N. T., Anh, T. N. and Kha, D. D. (2014). Development and application of Flood Vulnerability Indices for commune level - A case study in Lam river basin, Nghe An province, Vietnam. In: International Young Researchers Workshop on River Basin Environment and Management, Asian Institute of Technology, Thailand.

Kazakis, N., Kougias, I. and Patsialis, T. (2015). Assessment of flood hazard areas at a regional scale using an index-based approach and Analytical Hierarchy Process: Application in Rhodope-Evros region, Greece. Science of the Total Environment, 538, 555-563. https://doi.org/10.1016/j.scitotenv.2015.08.055

Kieu, T. D. and Thanh, L. D. (2011). A study on signals and zoning potential of high flood on lam river basin. Journal of Water Resources and Environment Engineering, 34, 3-8. (In Vietnamese)

Kieu, T. D. (2015). Large flood recognition study, large flood hazard zoning, and flood map building for warning the large flood in the Lam River basin. Scientific research project (Ministry level). (In Vietnamese)

Kieu, T. D. (2011). Research on large flood management in the Lam River basin. PhD thesis. Thuyloi University. (In Vietnamese)

Lawal, D., Matori, A., Hashim, A., Yusof, K. and Chandio, I. (2012). Detecting Flood Susceptible Areas Using GIS-based Analytic Hierarchy Process. In: International Conference on Future Environment and Energy. IPCBEE, vol. 28. Singapore.

Miller, G. (1956). The magical number seven, plus or minus two: Some limits on our capacity for processing information. Psychological review, 63 (2), 81-97. https://doi.org/10.1037/h0043158

Minh, D. T. and Dung, N. B. (2018). Application of GIS technology to establish a drainage density hierarchical map for flood hazard zoning in Lam river basin. Journal of Mining and Earth Science, 59 (6), 32-42.

Pallard, B., Castellarin, A. and Montanary, A. (2009). A look at the links between drainage density and flood statistics. Hydrology and Earth System Sciences, 13, 1019-1029. https://doi.org/10.5194/hess-13-10192009

Paweł, C. (2010). Using the analytic hierarchy process in evaluating decision alternative. Oper. Res. Decis., $20(1), 1-23$.

Phuong, T. T., Minh, P. T. and Ngoc, N. B. (2015). Application GIS and AHP to build the flood hazard zoning map in the Huong River basin, Thua Thien Hue province. Hue University Journal of Science, 13 (112). 
Rahmati, O., Zeinivand, H. and Besharat, M. (2016). Flood hazard zoning in Yasooj region, Iran, using GIS and multi-criteria decision analysis. Geomatics, Natural Hazards and Risk, 7 (3), 1000-1017. https:// doi.org/10.1080/19475705.2015.1045043

Saaty, T. L. (1987). The Analytic Hierachy Process - what it is and how it is used. Mathematical modelling, 9 (3-5), 161-176. https://doi.org/10.1016/0270-0255(87)90473-8

Saaty, T. L. (2008). Decision making with the analytic hierarchy process. International Journal Services Sciences, 1 (1), 83-98. https://doi.org/10.1504/IJSSci.2008.01759

Siddayao, G. P., Valdez, S. E. and Fernandez, P. L. (2014). Analytic Hierarchy Process (AHP) in Spatial Modeling for Floodplain Risk Assessment. International Journal of Machine Learning and Computing, 4 (5), 450-457. https://doi.org/10.7763/IJMLC.2014.V4.453

Sohl, T. and Benjamin, S. (2012). Role of remote sensing for land-use and land-cover change modeling. In: P. G. Chandra, ed., Remote Sensing of Land Use and Land Cover: Principles and Applications, CRC Press, Boca Raton, 225-239. https://doi.org/10.1201/b11964-18

Tu, L. H., Hong, N. T., Liem, N. D. and Loi, N. K. (2013). Integrating Analytic Hierarchy Process and GIS for Flood risk zoning in Vu Gia Watershed, Quang Nam Province, VNU Journal of Science, 3 (29), 64-72. (In Vietnamese)

Wischmeier, W. H. and Smith, D. D. (1978). Predicting rainfall erosion losses. In: A guide to conservation planning with Universal Soil Loss Equation (USLE). Agriculture Handbook no. 703. Department of Agriculture, Washington, D. C.

World Bank. (2017). Environmental Assessment (EA). Viet Nam Managing Natural Hazards Project (VNHaz/WB5), E2993 v4.

Received: March 1, 2020

Accepted: October 19, 2021

Contact information:

Nguyen Ba Dung — nbdung@hunre.edu.vn

Nguyen Quynh Nga — nganq@napa.vn

Pham Thi Lan - phamthilan@humg.edu.vn

LeThiLe_letl@tdmu.edu.vn

Dang Tuyet Minh — dtminh@tlu.edu.vn

\section{Оценка и подтверждение опасных для наводнений зон с использованием метода анализа иерархий и ГИС: исследование бассейна реки Лам (Вьетнам)}

Нгуен Ба Дунгㄹ, Нгуен Куин Нга ${ }^{2}$, Фам Тхи Лан ${ }^{3}$, Ле Тхи Ле

${ }^{1}$ Ханойский университет природных ресурсов и окружающей среды,

Вьетнам, Ханой, район Бак Ту Лием, приход Фу Дьен, ул. Фу Дьен, $41 \mathrm{~A}$

${ }^{2}$ Национальная академия государственного управления,

Вьетнам, Ханой, Донг Да, Ланг Тхыонг, ул. Нгуен Чи Тхань, 77

${ }^{3}$ Ханойский университет горного дела и геологии,

Вьетнам, Ханой, район Бак Ту Лием, приход Дук Тханг, ул. Вьен, 18

4 Университет Тхузаумот,

Вьетнам, Биньзыонг, Тхузаумот, Фу Хоа, Тран Ван Он, 6

${ }^{5}$ Университет Туилой,

Вьетнам, Ханой, Донг Да, Чунг Лиет, Тай Сон, 175

Для цитирования: Nguyen, Ba Dung, Nguyen, Quynh Nga, Pham, Thi Lan, Le, Thi Le, Dang, Tuyet Minh. (2021). Evaluation and validation of flood hazard zoning using Analytical Hierarchy Process and GIS: A case study of Lam River basin (Vietnam). Вестник Санкт-Петербургского государственного университета. Науки о Земле, 66 (4), 831-851. https://doi.org/10.21638/spbu07.2021.410 
В последние годы бассейн р. Ка (Лам) пострадал от различных стихийных бедствий, таких как затопления, подтопления, ураганы, торнадо и т. д. Среди всех бедствий наводнения оказались самой большой угрозой для жизни людей и социально-экономического развития окружающей территории. Более того, наводнения случались очень часто по сравнению с другими стихийными бедствиями. С учетом того, что подобные катастрофические наводнения все еще повторяются, возникает необходимость определения причин и анализа факторов, влияющих на возникновение наводнения. Это важно для развития системы раннего предупреждения о наводнениях и, таким образом, минимизации негативного воздействия наводнений в бассейне реки Лам на людей и инфраструктуру. В данной статье метод анализа иерархий (МАИ), интегрированный с технологией ГИС, используется для картографирования зон риска затопления в бассейне р. Лам. Параметры, использованные для анализа, являются основными факторами наводнения. Кроме того, в дополнение к пяти наиболее часто используемым факторам, таким как крутизна склонов, осадки, растительный покров, почва и густота речной сети, данное исследование также учитывает новый фактор - относительную длину склона, для построения более точной и надежной модели. Результаты сравнивались с двумя другими методами картографирования зон риска затопления на той же исследуемой территории: методом факторного анализа риска наводнений и методом наследования, анализа данных и их обработки. Результаты также были подтверждены историческими данными о наводнениях за три года, 2010, 2013 и 2016 годы.

Ключевые слова: метод анализа иерархии (МАИ), ГИС, бассейн реки Лам, карта зон опасности наводнений, Вьетнам.

Статья поступила в редакцию 1 марта 2021 г. Статья рекомендована к печати 19 октября 2021 г.

Контактная информация:

Нгуен Ба Дунг — nbdung@hunre.edu.vn

Нгуен Куин Нга - nganq@napa.vn

Фам Тхи Лан - phamthilan@humg.edu.vn

Лe Txu Лe - letl@tdmu.edu.vn

Данг Тайет Минх — dtminh@tlu.edu.vn 